\title{
Aerial inventory of surficial geological effects induced by the recent Emilia earthquake (Italy): preliminary report
}

\author{
Giovanni Bertolini ${ }^{1}$, Chiara Fioroni ${ }^{2}$ \\ ${ }^{1}$ Regione Emilia-Romagna, Servizio Tecnico dei Bacini Affluenti del Po, Reggio Emilia, Italy \\ ${ }^{2}$ Università di Modena e Reggio Emilia, Dipartimento di Scienze Chimiche e Geologiche, Modena, Italy
}

\author{
Article history \\ Received July 18, 2012; accepted August 21, 2012. \\ Subject classification: \\ Earthquake, Liquefaction, Geological effects, Aerial survey.
}

\section{Introduction}

As a consequence of the two main shocks that recently struck the central alluvial Po Plain (May 20, 2012, $\mathrm{M}_{\mathrm{L}}$ 5.9, and May 29, 2012, $M_{L} 5.8$ ), a great number of surficial geologic disturbances appeared over a wide area $\left(\mathrm{ca} .500 \mathrm{~km}^{2}\right)$, which extended up to $20 \mathrm{~km}$ from the epicenters. The affected area includes Mirabello, San Carlo, Sant'Agostino (Province of Ferrara), San Felice, Cavezzo, Concordia (Modena), Moglia and Quistello (Mantova).

Most of the surficial effects that were observed during this study were clearly induced (directly or indirectly) by sand liquefaction phenomena, such as sand volcanoes, burst of water and sand from domestic wells, tension cracks, lateral spreading and associated deformation, graben-like fracturing, and sink-holes. Other effects can probably be ascribed simply to the shaking of the ground (e.g., small collapses of irrigation canal walls). Lastly, there were also some features of dubious origin, such as two 'yellow crop spots' that are cited here with reservations.

All of these data were surveyed by means of a small airplane that was especially adapted for this purpose.

The aim of this study was to furnish a wide-ranging image of the surface deformation over the whole area impacted by these recent earthquakes, as an instrument towards more exhaustive research, both at the scientific and technical levels (e.g., seismic microzonation).

\section{Geological framework}

The subsiding Apenninic perisutural basin of the Po Plain contains a thick succession of Pliocene-Quaternary sediments of marine and continental origin, with a thickness that reaches as much as $1000 \mathrm{~m}$. In the study area, the $15 \mathrm{~m}$ to $20 \mathrm{~m}$ at the top of this succession have been ascribed to the Holocene.

For a thickness of several hundreds of meters, the subsoil of this area is formed by clay, silt and sand deposited by the River Po and its tributaries over the last seven hundred thousand years (Figure 1). These sediments represent the more recent phases of replenishment of the basin, which is linked to the uplift of the northern Apennines [Regione Emilia-Romagna 1988].

The topographic surface shows long and smooth ridges (the so-called dossi) that are formed by sandy channel-fill deposits, levees (natural and artificial), and crevasse splays, that are related to the ancient paths of the Rivers Secchia, Panaro and Reno, which were abandoned in the period between the 10th and 17th century [Regione Emilia-Romagna 1999]. Clay, silt and peat deposits prevail in the wider and lower overbank areas (the valli). The subsoil is formed by a succession of these lithologies, due to the permanent migration of rivers in the alluvial plain since the middle Pleistocene.

Human activity has strongly influenced the present landscape since medieval times, by the draining and raising of the surface of swamps through landfill practices, by creating artificial ditches and canals, by diverting the natural flows of waters and retaining them inside artificial levees. In the whole study area, the groundwater level is very close, if not coincident, to the surface.

In summary, the subsoil of this area shows all of the combined predisposing factors that allow the liquefaction of sands during strong earthquakes.

\section{Surface effects}

The first observed events were related to the shock of May 20, 2012, with its epicenter near Massa Finalese (Modena). This earthquake most strongly impacted a region to the east of Mirandola: in particular, the villages of San Carlo and Sant'Agostino (ca. $16 \mathrm{~km}$ from the epicenter), Mirabello $(20 \mathrm{~km})$, Dodici Morelli $(11 \mathrm{~km})$, San Felice sul Panaro $(8 \mathrm{~km})$ and the region surrounding San Martino Spino $(12 \mathrm{~km})$ and Scortichino $(7 \mathrm{~km})$. 


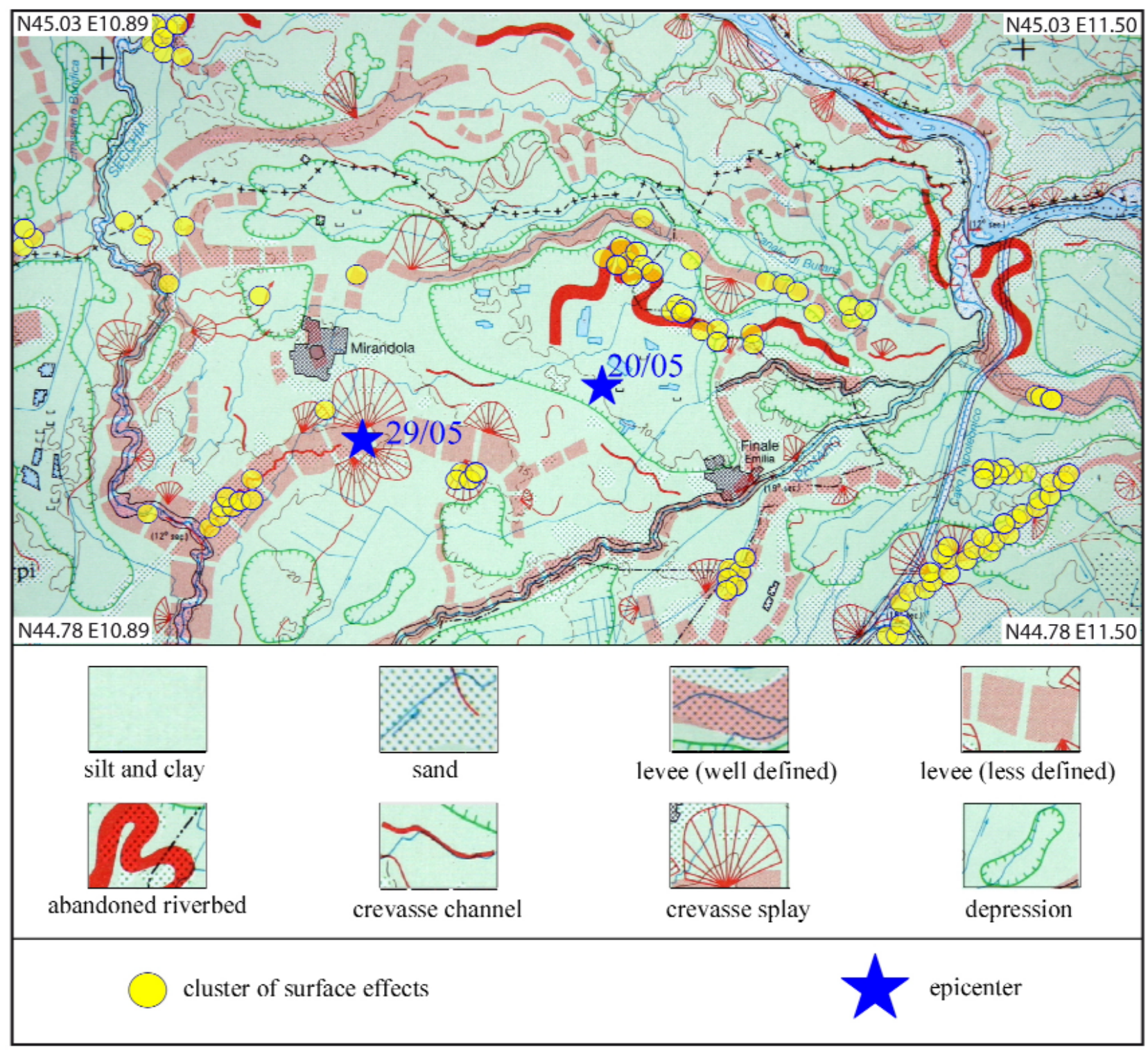

Figure 1. Sketch map of the surficial geological effects induced by the recent earthquakes, and their relationships with geomorphological features. Geomorphological map from Castiglioni et al. [1997].

The other main shock on May 29, 2012, occurred near Medolla, and it triggered similar effects in Cavezzo $(4.5 \mathrm{~km}$ from the epicenter), Motta $(9 \mathrm{~km})$, Concordia (10 km), Quistello (19 km), Moglia (16.7 km), and reactivated the ones already observed in San Felice $(5 \mathrm{~km})$ and near San Martino Spino (14 km).

The most spectacular effects were represented by the eruption of sand, which formed small volcanoes, and the bursting of water and sand from domestic wells. Long tension cracks (up to some hundreds of meters in length), 'grabens', and large lateral spreads formed within the village of San Carlo (Ferrara).

\section{Field survey}

Considering that rain, vegetation, and human activity would quickly obliterate geomorphic evidence of the earthquakes, an aerial inventory of the impacted area was undertaken, using an especially adapted aircraft. The inventory was collected under the ideal conditions of low speed-low altitude capability of the aircraft, simplicity of using the equipment, and low operational cost. The survey was conducted at the average altitude of $200 \mathrm{~m}$ over a two-week period. More than 700 geological features were inventoried and documented by 300 aerial photographs and their related GPS coordinates. In total, about 2000 high-definition digital photographs were taken and examined in a post-flight analysis. In this way, it was possible to also recognise small effects, of only $1 \mathrm{~m}^{2}$ in area. Some $500 \mathrm{~km}^{2}$ of the territory were systematically checked in this way, during 15 sorties and 20 $\mathrm{h}$ of flight. Systematic checks on the terrain were performed, to reduce the number of errors in the interpretation of photographs.

The observational accuracy depended on the short time that elapsed between the earthquakes and the survey. Within one week of the shocks, the sand remained wet and appeared clearly on the terrain; after that time, the sand became dry 


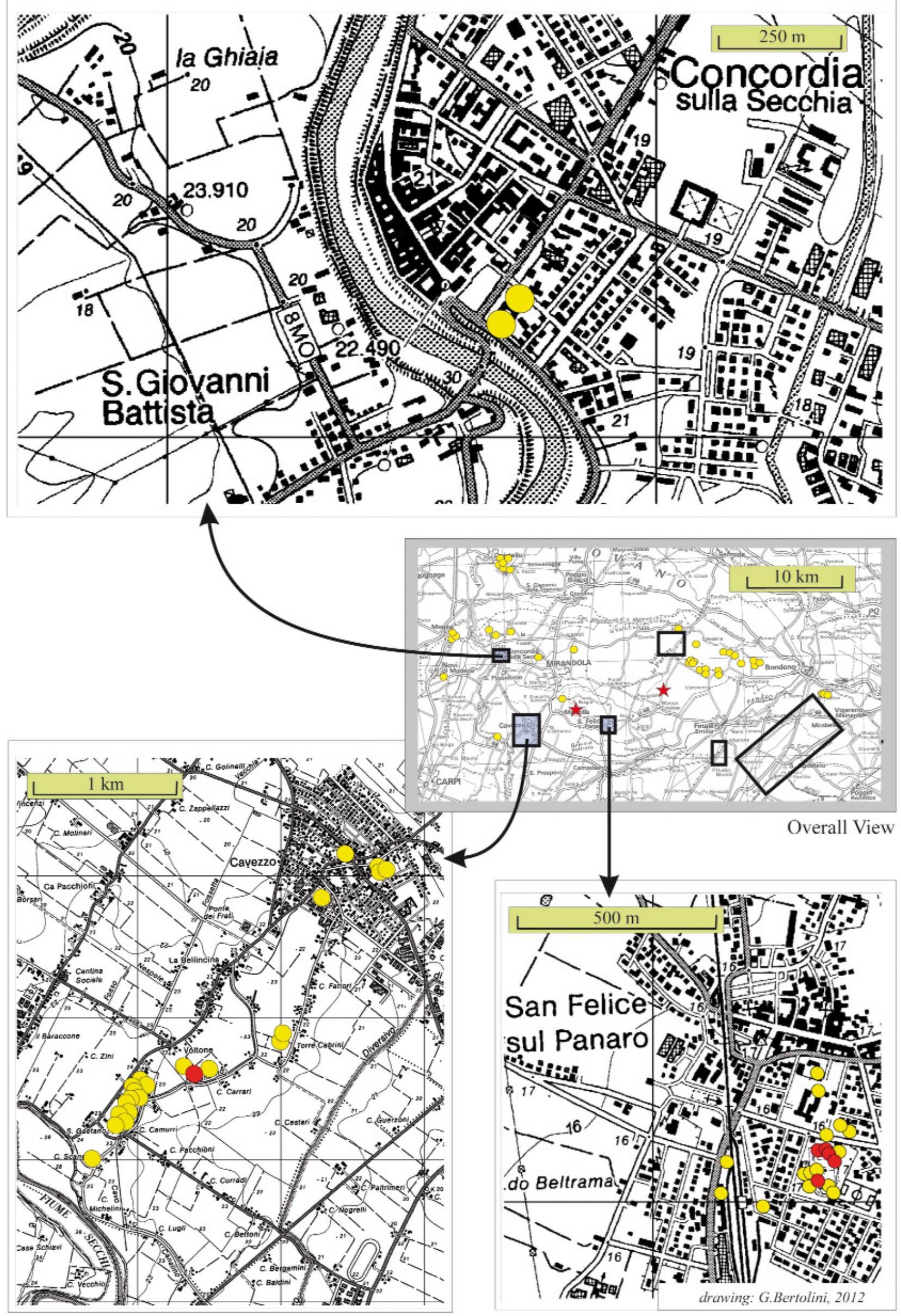




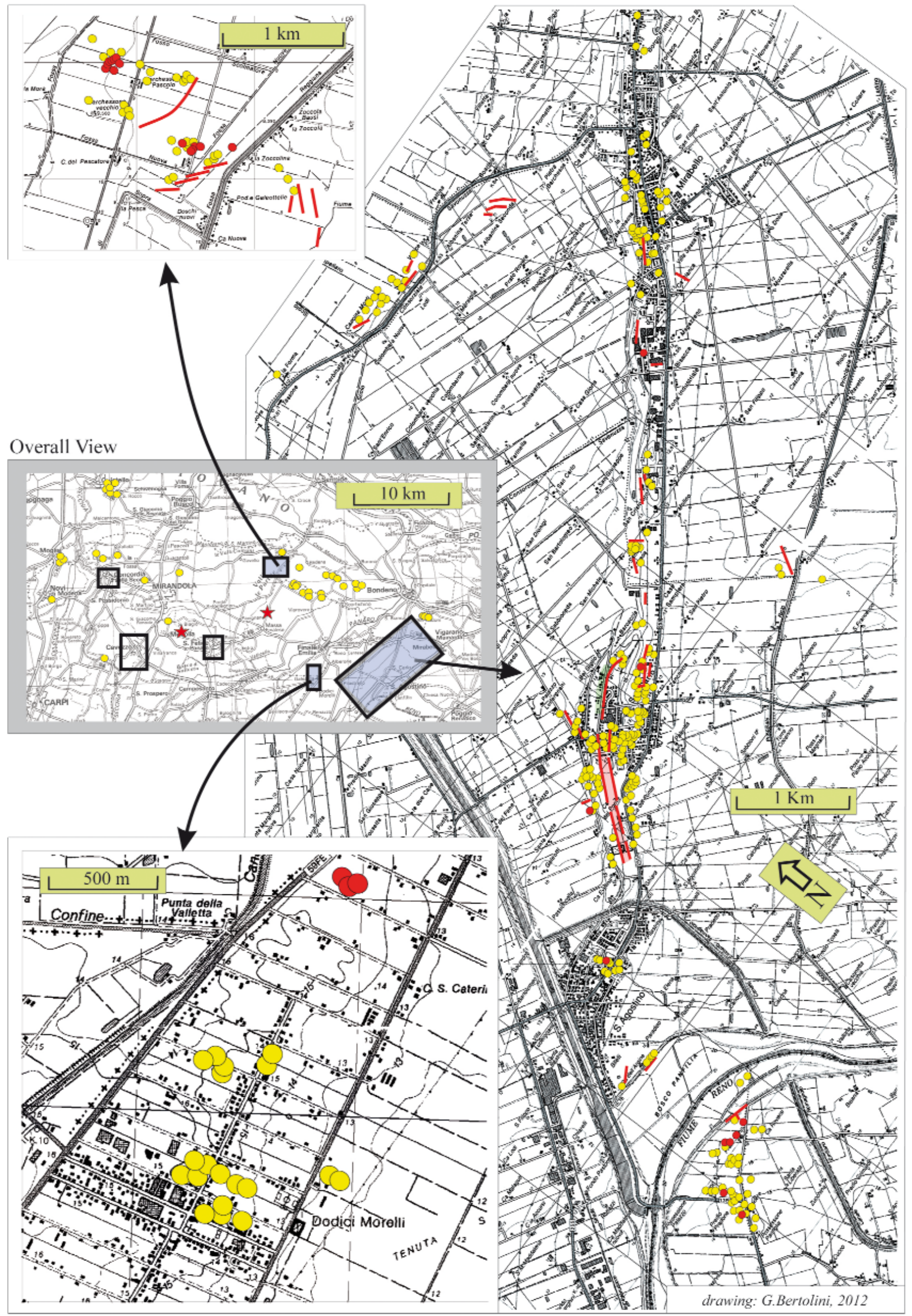

Figure $\mathbf{2 b}$. Simplified maps of the observed geological effects. For symbols see text. 
and was more difficult to recognise, especially in an urban context. In open fields, these features remained clearly visible for several weeks, even if vegetative regrowth and cultivation have now obscured the effects.

The following types of features were recognized:

a. Sand volcanoes (punctual);

b. Eruption of wet sands from ground fissures;

c. Eruption of wet sands from foundations (usually along the perimeters of buildings);

d. Eruption of sands (and water) from domestic wells;

e. Tension cracks and graben-like fissures (without or with eruption of sand or water);

f. 'Dry' craters (or sink-holes) of average diameters of 1-2 m; g. Lateral spreading effects (on slopes);

h. Small collapses along the banks of irrigation ditches; i. 'Yellow corn spots' due to local corn withering (saltwater/ gas/heat emissions?).

Seventy percent of the observed effects occurred within town and village boundaries (Figure 3.2), while the remaining $30 \%$ was observed in open agricultural fields and was characterized almost exclusively by features of types 'a', 'b' and 'e'.

A simplified map of the aerial inventory is shown in Figure 2a,b. Due to the large amount of data collected in the original inventory (about 700 datapoints), each point in these figures might represent one or more data points. The main aim of these maps is to provide a picture of the spatial distribution of the collected data in relation to the epicenters. The yellow dots in Figure 2a,b represent sand volcanoes, eruption of sand from short cracks, and bursts of sand and water from domestic wells. The red symbols represent short (dots) or long (lines) fissures in the ground, without or with the eruption of sand. The red stars are the epicenters of the main shocks (easternmost: May 20, 2012, $\mathrm{M}_{\mathrm{L}}$ 5.9; westernmost:May 29 2012, $\mathrm{M}_{\mathrm{L}}$ 5.8).

In the inventory, the data are geo-referenced and accompanied by a short description and one or more aerial photographs (examples are shown in Figures 3, 4 and 5). In Figure $2 \mathrm{~b}$, some peculiar features are visible inside the town of San Carlo (Sant'Agostino municipality): the 'graben' (light red) and the tension cracks (light green).

\section{Conclusions}

These observations indicate that most of the sand eruptions and tension fissures follow the sinuous paths of abandoned rivers and their sandy deposits. These observations are consistent with what has been reported for ancient dossi,
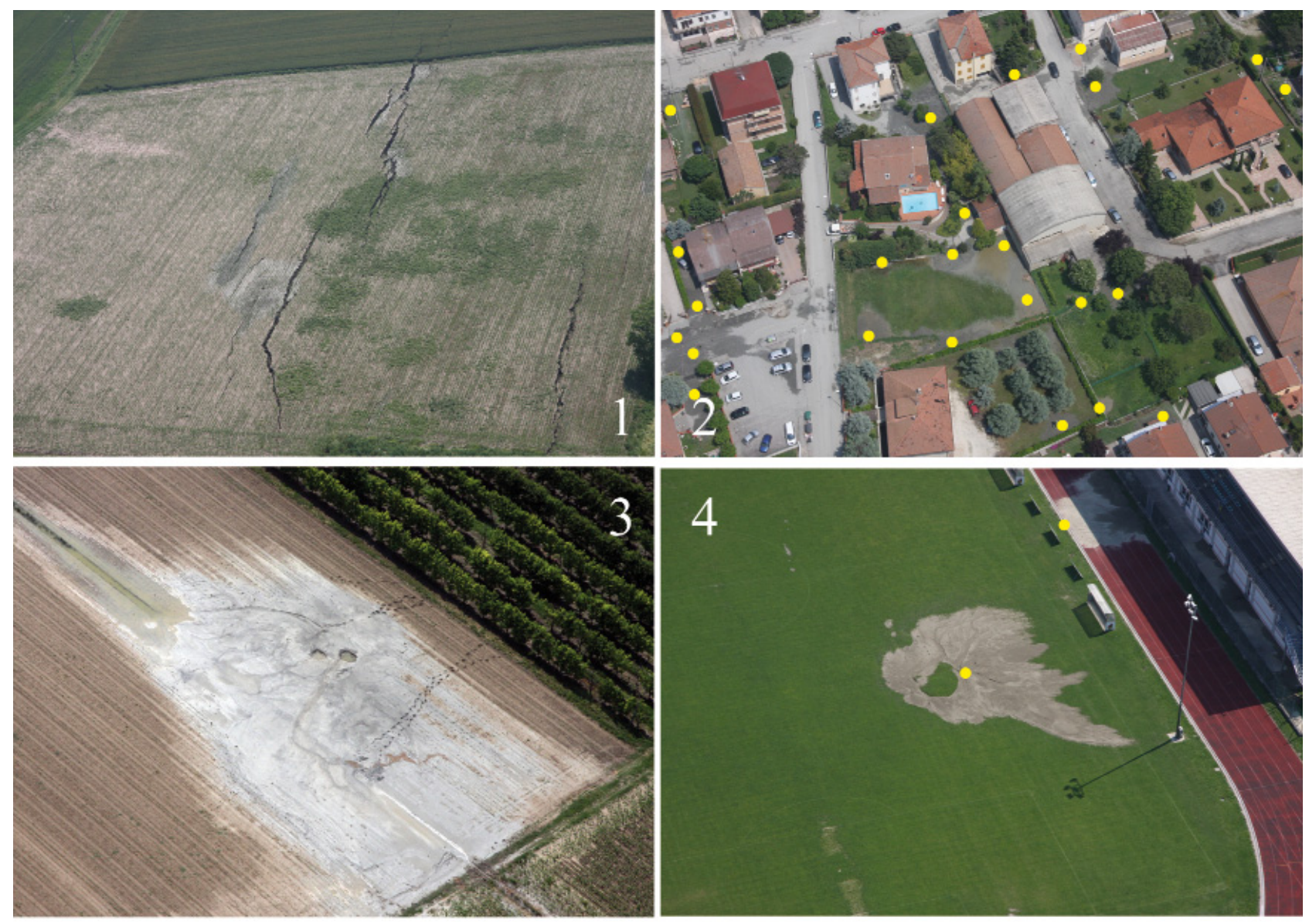

Figure 3. Some examples from the mapped surficial effects. 1) Long tension cracks (up to $1 \mathrm{~m}$ in width and $2 \mathrm{~m}$ in depth) and 'grabens' south of San Carlo (Ferrara Province); 2) Sand eruptions (yellow spots) from wells, cracks and foundations inside the town of San Carlo; 3 ) eruption of sand in an open field; note the formation of small craters; and 4) eruption of sand in San Felice sul Panaro football field (Modena Province). 

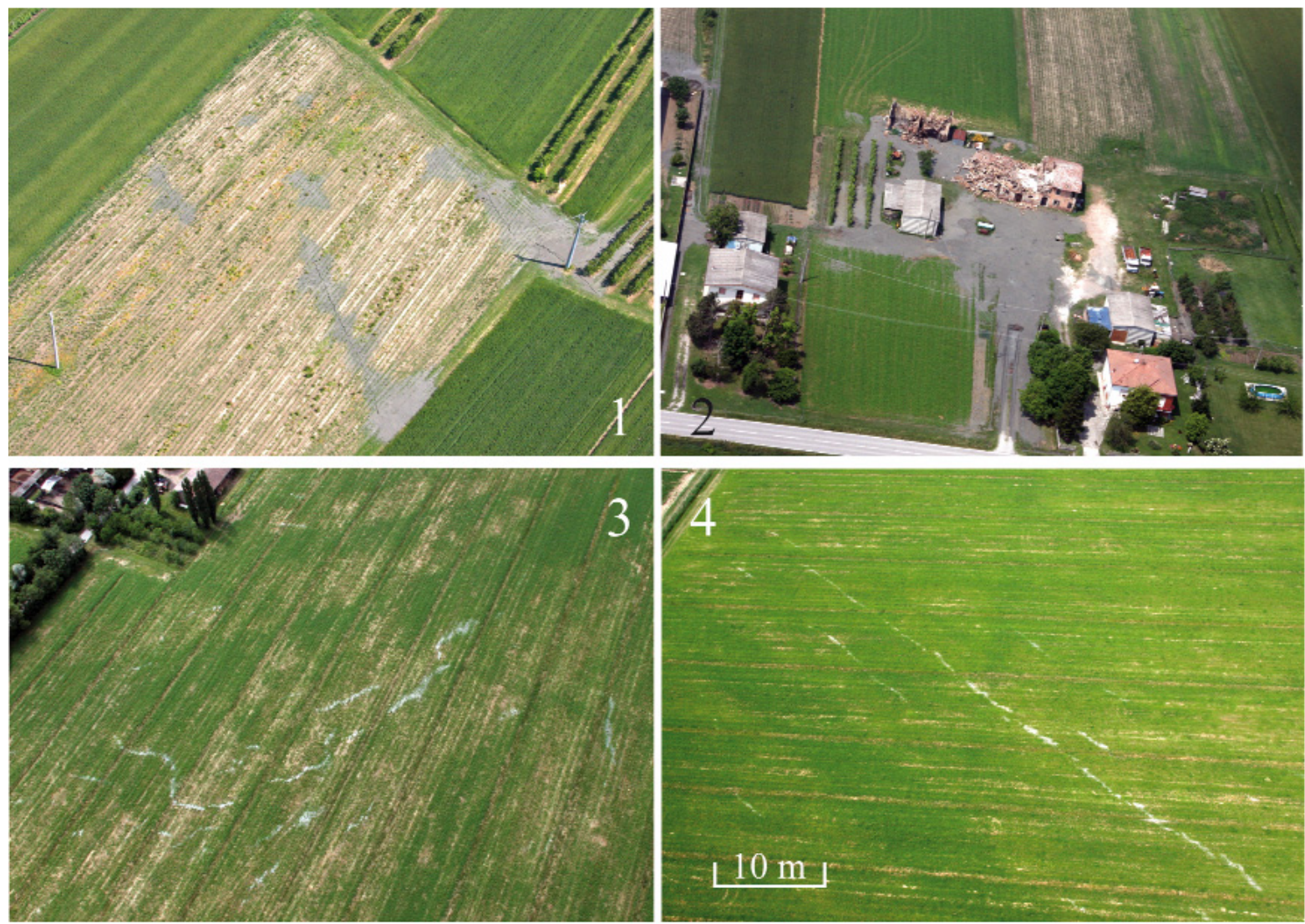

Figure 4. 1) Fractures near Sant'Agostino (Ferrara Province); 2) Eruption of sand North of San Carlo; 3), 4) These fractures retrace the forms of ancient watercourses, now abandoned (Modena Province).
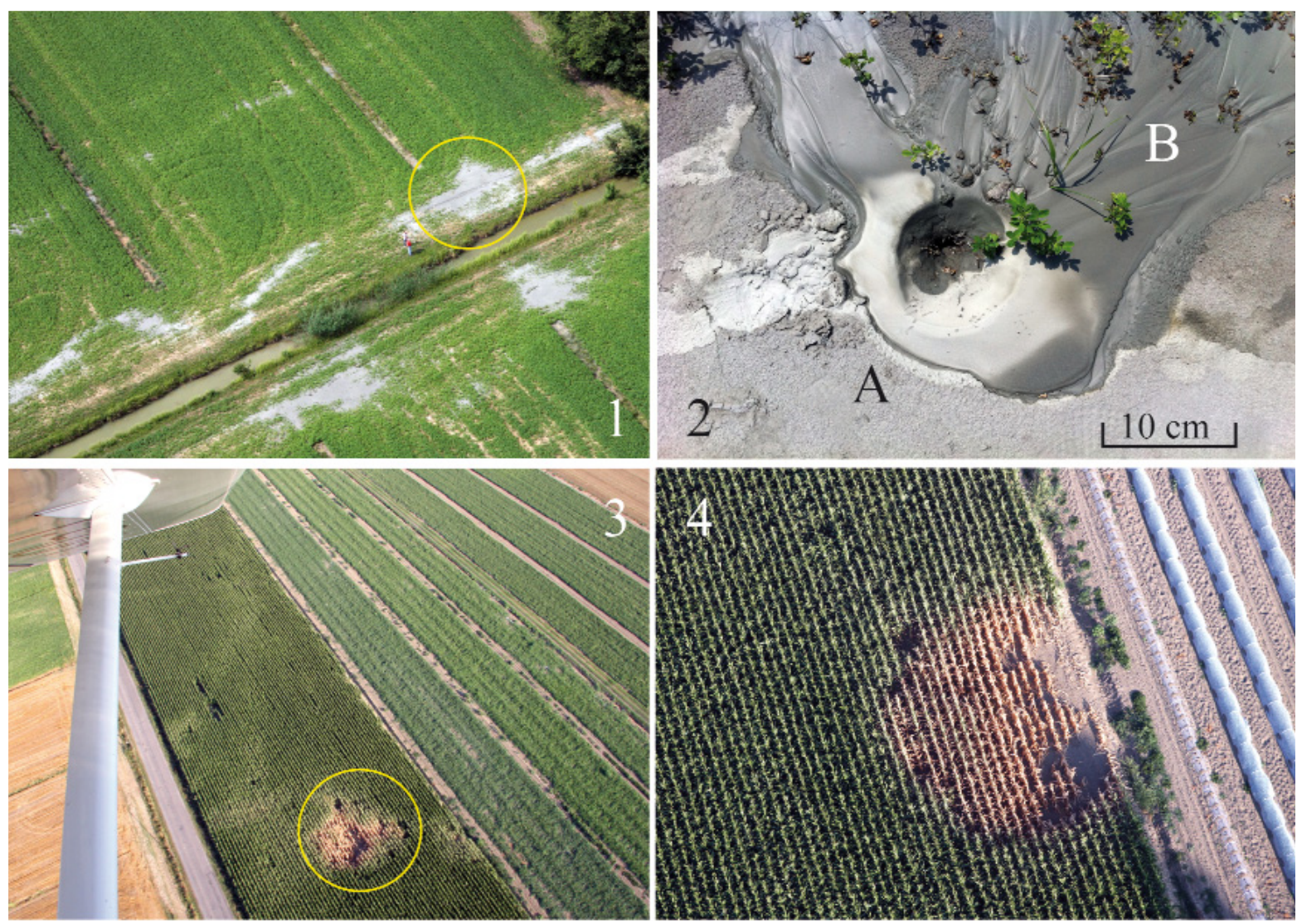

Figure 5. 1) Several 'sand volcanoes' near San Martino Spino (Modena Province). 2) Vertical close-up detail from panel (1) (yellow circle): the 'new' mud (B) erupted after the May 29 mainshock covered the sand (A) that erupted on May 20. 3), 4) Evidence of effects of dubious origin in corn plantations near Medolla (N $44.85^{\circ}$; E $011.08^{\circ}$ ), near to the May 29 epicenter. 
which has patterned the location of towns and associated modern infrastructure (see Castiglioni et al. 1997, Figure 1). In some cases, also ancient artificial banks and land fill might have been affected.

An important exception to this correspondence is represented by the cluster of data in the so-called 'Valli di Mirandola' south of San Martino Spino, that was a relatively recent bed of the Po River, but now abandoned (Figures $2 \mathrm{~b}$, $4.3,4.4,5.1,5.2)$. In some cases, the liquefaction occurred on ancient crevasse splays, like mostly in the San Carlo case. A large number (70\%) of these effects were concentrated inside towns, so demonstrating a close relationship with the presence of buildings and domestic wells.

Even if in a preliminary form, this aerial inventory raises some interesting elements of discussion. One is related to the spatial distribution of these liquefaction effects: a large number of them occurred at a considerable distance from the epicenters (up to $20 \mathrm{~km}$ away), whereas only $10 \%$ occurred within the radius of $5 \mathrm{~km}$.

Two evident spots of withered corn about $20 \mathrm{~m}$ in diameter (Figure 5.3 and 5.4) were perhaps related to saltwater, gas or heat emissions, and these were observed and documented near Medolla (just near the May 29 epicenter). These are not new features as they had been known and documented since the XVII century [Spinelli et al. 1893, and further references in Gorgoni and Tosatti 2004]. As a consequence, a close relationship with the recent earthquake should be considered dubious. For this reason, these effects are cited here but do not appear in the aerial inventory.

Regarding the data survey, we highlight the versatility of the utilized aerial vector. The high-wing, two-seats Tecnam P92 aircraft allowed us to accomplish the whole survey with the maximum of accuracy and at very low overall costs (about 2000 Euros).

This work integrates other similar surveys performed in the same area and period [e.g., EMERGEO Working Group. 2012, this volume] completing the exhaustive picture of the occurred phenomena.

The complete aerial inventory has been used to draw maps for the competent authorities [Regione Emilia-Romagna 2012] and is available for scientific and technical purposes. In particular, it has been a useful base-map for the collection of a series of samples, carried out by DST-Unimore (Dipartimento di Scienze della Terra, Modena and Reggio Emilia University) in order to perform a complete analysis of these sands in the whole territory (in progress).

In the near future, this inventory might also be useful in territorial planning, to perform more accurate hazard assessment.

Acknowledgements. We express our gratitude to Frank Pazzaglia and Vincenzo Picotti for their suggestions and constructive comments on the manuscript.

\section{References}

Castiglioni, G.B., A. Biancotti, M. Bondesan, D. Castaldini, M. Ciabatti, M. Cremaschi, V. Favero and G.B. Pellegrini (1997). Geomorphological Map of Po Plain (scale 1:250.000). Ministero dell'Università e della Ricerca Scientifica e Tecnologica, S.EL.CA, Firenze.

EMERGEO Working Group (2012). Technologies and new approaches used by the INGV EMERGEO Working Group for real-time data sourcing and processing during the Emilia Romagna (northern Italy) 2012 earthquake sequence, Annals of Geophysics, 55 (4); doi:10.4401/ag6117.

Gorgoni, C., and G. Tosatti (2004). Emissioni di metano e fanghi salmastri oleosi da un pozzo dismesso in Comune di Concordia sulla Secchia (Provincia di Modena). Atti della Società dei Naturalisti e Matematici di Modena, 117, 155-174.

Regione Emilia-Romagna (1988). Riserve Idriche Sotterranee della Regione Emilia-Romagna, Relazione Tecnica, G. Di Dio (ed.), S.EL.CA, Firenze.

Regione Emilia-Romagna (1999). Carta Geologica di pianura dell'Emilia-Romagna alla scala 1:250.000, D. Preti (ed.), S.EL.CA, Firenze.

Regione Emilia-Romagna (2012). Carta degli effetti di liquefazione osservati dopo i terremoti del 20 e 29 Maggio 2012; http:/ / geo.regione.emilia-romagna.it/gstatico/ documenti/liq2012/MAPPA_LIQUEFAZIONI_01.pdf.

Spinelli, A.G., and A. Cuoghi Costantini (1893). Una salsa e terre calde in Medolla, Il Panaro - La Gazzetta di Modena, XXI, 117, 30 aprile 1893, Modena.

\footnotetext{
${ }^{\star}$ Corresponding author: Giovanni Bertolini, Regione Emilia-Romagna, Servizio Tecnico dei Bacini Affluenti del Po, Reggio Emilia, Italy; email: gbertolini@regione.emilia-romagna.it.

(C) 2012 by the Istituto Nazionale di Geofisica e Vulcanologia. All rights reserved.
} 